\title{
Achieving Program Outcomes through MIY model ensuring active learning and active engagement in Learning
}

\author{
Dr Vinay Kulkarni ${ }^{1}$, Dr Maneetkumar Dhanvijay ${ }^{2,}$ Dr Mrs P Malathi ${ }^{3}$, Dr Vijay M Wadhai ${ }^{4}$, Dr. Sameer S \\ Sahasrabudhe 5 \\ ${ }^{1}$ Associate Professor, Mechanical Engineering Department, D Y Patil College of Engineering, Akurdi, Pune \\ ${ }^{2}$ Assoicate Professor, Production and Industrial Management Department, College of Engineering, Pune \\ ${ }^{3}$ Professor and Vice Principal, D Y Patil College of Engineering, Akurdi, Pune \\ ${ }^{4}$ Principal, D Y Patil College of Engineering, Akurdi, Pune \\ ${ }^{5}$ Senior Research Scientist, NPTEL, IIT Bombay
}

\begin{abstract}
Post Covid-19 is a real challenge, as students' faces are not visible to teachers during interaction or nor the students are available physically, leaving teachers clueless about their active learning and active engagement in learning. Achieving graduate attributes poses further challenge as it has to ensure imbibing Higher Order Thinking skills [HOTs] in students. There is a need to develop online integrated pedagogy to overcome this problem. It is observed that creating content specific videos, really creates interest in students and ensures active learning, if they are asked to upload in YouTube provided students are guided with Rubric based learning for video creation. Moodle integrated YouTube [MIY] channel is developed to let the teachers create their own Video of short duration with rubric guidance. The paper presents a case study dedicated to PO7 [Program Outcome Environment and Sustainability], supported by Open Education for better World [OE4BW]. The Moodle based methodology [73 activities in MoodleGames like crossword, Quiz, Discussion Forum], integrating with google meet to interact with participants, Rubric guidance, query solving, active learner's motivation and impact of posting in YouTube channel are presented in study.

Out of 268 participants, 217 participants peer reviewed videos were selected and added in YouTube channel [Environment and sustainability OE4BW, https://www.youtube.com/channel/UCQWwEFdEMeS7Kc $3 \mathrm{MuWw} 3 \mathrm{Jkg} / \mathrm{videos}$ ] based on quality content [Carbon foot print analysis, Environment and Sustainability computation] created by them. Participant's happiness index for learning was attributed as A+ [4.79/5] during the entire video development process.
\end{abstract}

Keywords: Post Covid-19, PO7, Carbon Emission, Youtube Assignment, Active Learning, Learning Satisfaction

\section{Corresponding Author}

Dr Vinay Kulkarni, Associate Professor, Mechanical Engineering Department, D Y Patil College of Engineering, Akurdi, Pune, India.

vakulkarni@dypcoeakurdi.ac.in

\section{Introduction}

Achieving Program Outcomes (POs) during Covid-19 is challenging as active learning practices will be difficult to achieve due to limitation of online education. Program Outcomes are the skills, knowledge, and technical aptitude to be developed in students. The questions/activities to be framed in such a way that, students not only completes the exercise, but also they should feel the learning satisfaction. [1]. During covid-19, most important activity is to train teachers to practice blended learning and going beyond online teaching [1].

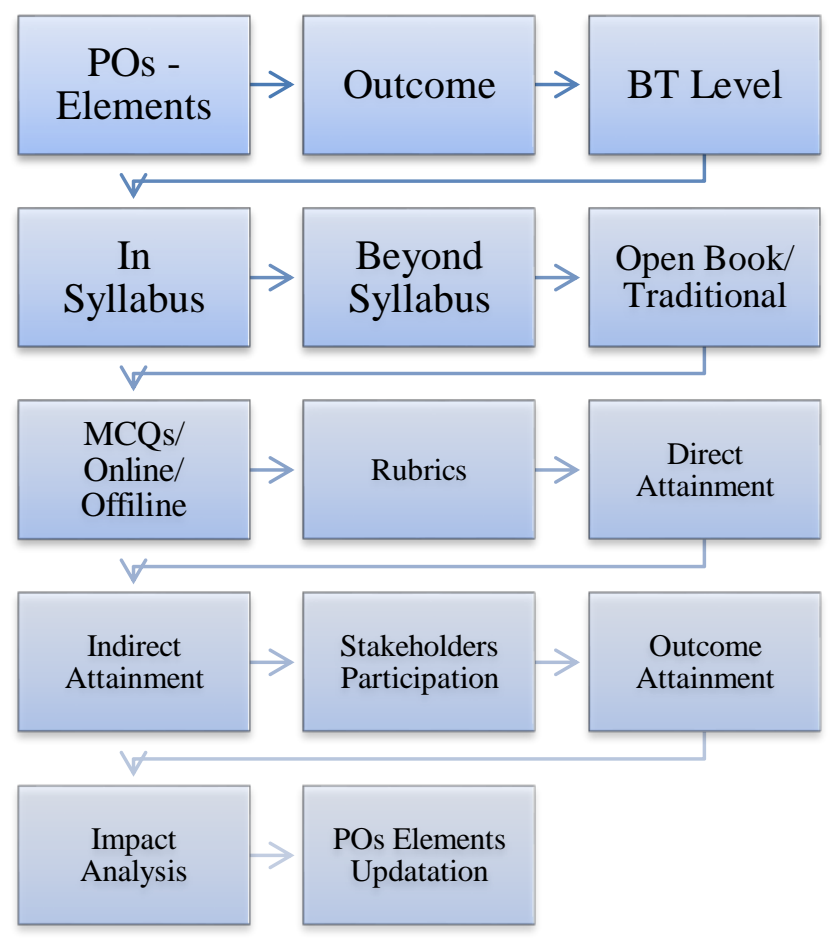

Fig 1: POs Attainment Activities

As shown in Fig 1, POs contains various elements, for example in PO7, environment and sustainability are two different elements. Intended outcome must be finalized before deciding any learning activity, like students will calculate carbon emission during manufacturing or operating computers etc.

Lower order thinking skills, do not lead to employable outcomes to students due to lack of critical thinking skills. Instead it is observed that, LOTs questions can be easily found with their answers in Open Source, digitally. Students 
tend to copy these answers directly with/without analysing its consequences on their learning effectiveness. Teachers, if they don't made students to realize it, desired BT (Blooms Taxonomy) level effectiveness is not achieved. Confining only to prescribed syllabus, (especially true with affiliated education system) is not at all desirable. In addition to prescribed syllabus, beyond curriculum is most desirable to achieve higher order thinking skills. Students' survey indicated that, $95 \%$ of engineering students desires target of 1 Lakhs per month earnings after graduation. To achieve this by students, BT 5 level skills must be minimum achieved.

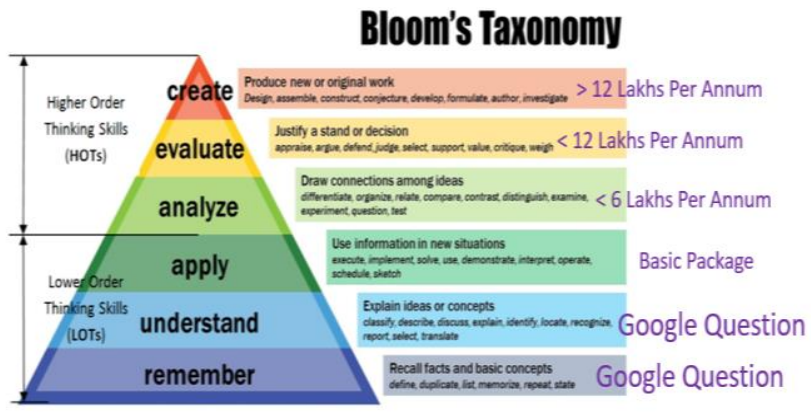

Fig 2: BT Level skills relationship with employability

However, it is realized that, this must be firstly trained to teachers as students copy answers easily if they find question as it is in open source.

Open book examinations are most practical like faced by students in real life, when they are working in field. It is also observed that, teachers to avoid framing of many questions which are original provoking critical thinking, tend to frame lower order thinking skills mug type questions.

Post Covid-19, teachers will have to think of infusing Open book examination questions in their learning assessment systems.

It is fact that, majority of employability examinations, like GATE (Basic level for recruitment in PSUs), IES/UPSC, and campus placement aptitude questions are also based on MCQs. One of the best feature of MCQ examination is, it helps students to develop, exploring choices between available options like in real life.

Many times, it was observed that, students are not well aware of expectations of teachers and development of skills, before solving any activities/or assignments. Rubrics will help, students to analyse teacher's expectations before putting efforts towards any activity. Students will then, put up more efforts and really achieve, examination is not just for marks/numbers, but to achieve skills and outcome.

Stakeholders' participation in development and assessment is infused during POs attainment procedures. Direct attainment is more tagged to teacher, and indirect attainment is tagged more to students and employers. It is also practically observed that if Alumni stakeholders' participation is infused it provides better result not only for attainment calculations but also skill development of student's refinement towards outcome.

Based on learning styles and predominantly active engagement in learning, students' outcome is achieved.
Learned Impact analysis by teacher during any activity, will further enhance the activities designed in future.

\section{Post covid-19 challenges in achieving program outcomes}

Post covid-19 poised sudden challenges in teaching-learning processes. Teachers can't read expressions on students face during interaction nor are the students available physically, leaving teachers clueless about their active learning and active engagement in learning. Due to it, achieving graduate attributes poses further additional challenges.

Today's students are net generation students and net based assignments like YouTube video creation creates real interest in the students. During various hackathons, project competitions, it is evident. Like AICTE Project Hackathon, likes, comments can also be used as peer feedback, which is important steps in outcome based education.

Moodle (Modular Object Oriented Dynamic Learning Environment) provides lot of opportunities to students and teachers, especially framing questions in higher order thinking skills, apart from using it as repository with all login, accessibility records.

A survey conducted across engineering teachers, made to realize that, PO7 (Program Outcome 7), Environment and Sustainability is highly critical to be taught to engineering students, as it involves making them aware about consequences related to carbon emissions, waste management, carbon management etc, as presented in Table 1

Table 1: PO7 [Disseminate to Teachers]

Environment and sustainability: Understand the impact of the professional engineering solutions in societal and environmental contexts, and demonstrate the knowledge of, and need for sustainable development.

\begin{tabular}{|c|c|}
\hline PO Elements & Issues to be addressed \\
\hline Environment & $\begin{array}{l}\text { Impact of environment and } \\
\text { Sustainability in professional case study, } \\
\text { Environmental context in different } \\
\text { programs of Professional education, } \\
\text { Calculations of } \mathrm{CO}_{2} \text { emission, Standards } \\
\text { related to environment like ISO 14000, } \\
\text { IEEE 2018, Standard operating } \\
\text { environment in IT, Software } \\
\text { development environment, Civil } \\
\text { engineering, Industrial environment, } \\
\text { Climate and Ecological conscious } \\
\text { leaders, Mathematics and Statistics } \\
\text { applied to environment, Environment } \\
\text { Impact Analysis (EIA), ISO } \\
\text { 14001:2015, Biodegradable and } \\
\text { Recycling Plastics, Solid Waste \& Water } \\
\text { Management, Solar Energy, Electric } \\
\text { Vehicles and Energy Storage }\end{array}$ \\
\hline Sustainability & $\begin{array}{l}\text { Sustainability Standards like ISO } 26000 \text {, } \\
\text { ISO guide 82:2019, Sustainable } \\
\text { materials, structures, Sustainability } \\
\text { computations, Green IT, Blockchain } \\
\text { based sustainable development, } \\
\text { Mathematics and Statistics applied to }\end{array}$ \\
\hline
\end{tabular}




\begin{tabular}{l} 
Table 1: PO7 [Disseminate to Teachers] \\
Environment and sustainability: Understand the impact \\
of the professional engineering solutions in societal and \\
environmental contexts, and demonstrate the knowledge \\
of, and need for sustainable development. \\
\hline PO Elements \\
$\begin{array}{l}\text { Issues to be addressed } \\
\text { statistics, Storage Membrane inventions } \\
\text { for water and Environment, Industrial } \\
\text { waste -water-treatment for re-use, low } \\
\text { energy solution }\end{array}$ \\
\hline
\end{tabular}

The paper presents a case study dedicated to PO7 [Program Outcome Environment and Sustainability], supported by Open Education for better World [OE4BW].

\section{MIY Model (Moodle Integrated YouTube Model)}

In Gnomio Moodle, teachers' participants were invited as part of Faculty Development Program (FDP) developed to impart learning on Program Outcome [PO7] [2,3].

Goals of this MIY Model are

$\checkmark$ Faculty will be able to compute carbon footprint, analyze carbon emissions in their specific subjects

$\checkmark$ Faculty will be able to realize importance of environmental friendly sustainable products and disseminate in their students

$\checkmark \quad$ Value environment and sustainability efforts in professional education and innovate methods to disseminate in students

$\checkmark \quad$ Critically Weigh sustainability computation and its impact on professional development

$\checkmark$ Create own model of environment and sustainability in own context

Teachers are considered as participants in this FDP. Intended outcomes of this FDP is

$\checkmark$ All faculty will create video YouTube OERs relevant to their subject specific content

Platform hosted for imparting PO7 is https://moodleians.gnomio.com [Dummy User Id: dummy2019, Password: Dummy\#2019] under course Environment and Sustainability [OE4BW] for imparting training, learning assessment after expert lectures (arranged in Google Meet), repository arrangements, Active learning strategies like Game pedagogy, Crossword, Snake and Ladder, Feedback of participants, QR coded certificate to participants upon successful completion of activities.

Total 652 teachers from 15 states of India, from engineering, pharmacy participated in FDP. Total 73 activities in Moodle, were organized helping teachers to frame their subject specific videos pertaining to environment and sustainability. 45 Expert lectures from 15 countries was organized to impart various case studies to participants to help them realize different approaches towards 17 Sustainable Goals of United Nations to be adopted by each country and disseminate to students through MIY model.

Topics of expert lectures were finalized as mentioned in Table 1, created interests in the participants and help them realize on their own, their subject specific matter relevant to environment and sustainability. One of the participant expressed his opinion about expert sessions in following way. All the expert were exceptionally knowledgeable from various fields of PO7:ES and different parts of the globe. Interacting with them was an amazing experience. Overall the efforts taken by the organising committee are incomparable and they have taken very hard efforts to get the experts from different parts of the world. Coordinators took every care to solve the problems and difficulties of the participants during the entire course. Coordinators were very cooperative and supportive throughout the programme. I would like to quote for organisers: "Whatever you do, do it well. Do it so well that when people see you do it they will want to come back and see you do it again and they will want to bring others and show them how well you do what you do."

-Walt Disney

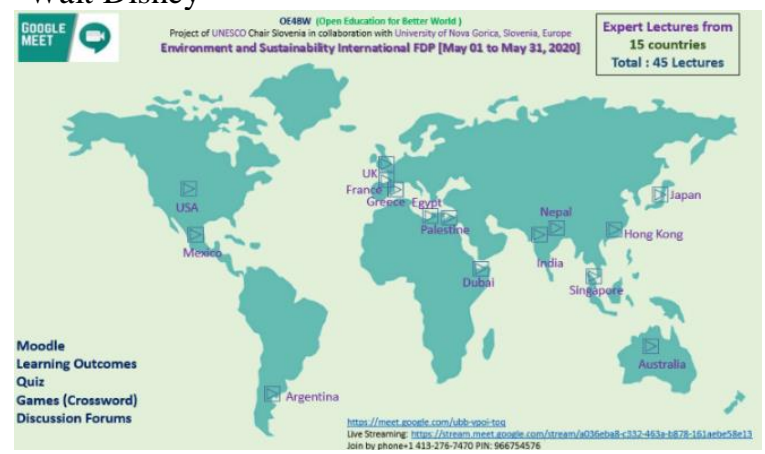

Fig 3: Expert Lecture Details

Arranging expert lectures all across globe helped to create interest in participants and brought confidence in their own.

3.1 YouTube Video creation based on Rubrics criterion

Rubrics helps participants to clearly apply and analyse the expectations and intended outcomes. Participants are then geared up to put their best of efforts.

Table 2, shows Rubrics criteria for developing subject specific YouTube Videos by participants.

\begin{tabular}{|c|c|c|c|c|}
\hline $\begin{array}{l}\text { Sr. } \\
\text { No. }\end{array}$ & $\begin{array}{l}\text { Criteria/ } \\
\text { Description }\end{array}$ & $\begin{array}{l}\text { Satisfactory } \\
{[1]}\end{array}$ & $\begin{array}{l}\text { Good } \\
{[2]}\end{array}$ & $\begin{array}{l}\text { Excellent } \\
\text { [3] }\end{array}$ \\
\hline 1 & $\begin{array}{l}\text { Standard } \\
\text { Templates } \\
\text { followed }\end{array}$ & $\begin{array}{l}\text { Title slide } \\
\text { without } \\
\text { subject } \\
\text { specific } \\
\text { content }\end{array}$ & $\begin{array}{l}\text { Title slide } \\
\text { with specific } \\
\text { content } \\
\text { without self- } \\
\text { photo }\end{array}$ & $\begin{array}{l}\text { Title slide } \\
\text { with title, } \\
\text { photo, } \\
\text { organization } \\
\text { details }\end{array}$ \\
\hline 2 & $\begin{array}{l}\text { YouTube } \\
\text { link of week } \\
1 \text { and week } 2\end{array}$ & $\begin{array}{l}\text { Not } \\
\text { mentioned } \\
\text { full details }\end{array}$ & $\begin{array}{l}\text { Full details } \\
\text { are } \\
\text { mentioned }\end{array}$ & $\begin{array}{l}\text { Full details } \\
\text { can be } \\
\text { validated }\end{array}$ \\
\hline 3 & $\begin{array}{l}\text { Video } \\
\text { Outcomes }\end{array}$ & $\begin{array}{l}\text { BT LOTs } \\
\text { action verbs } \\
\text { are used }\end{array}$ & $\begin{array}{l}\text { BT HOTs } \\
\text { action verbs } \\
\text { are used }\end{array}$ & $\begin{array}{l}\text { BT HOTs } \\
\text { verbs specific } \\
\text { to content is } \\
\text { used. }\end{array}$ \\
\hline 4 & $\begin{array}{l}\text { ISO/IEEE or } \\
\text { other } \\
\text { company } \\
\text { specific } \\
\text { standards (> } \\
\text { 1) }\end{array}$ & $\begin{array}{l}\text { Mentioned } \\
\text { but not in } \\
\text { table format }\end{array}$ & $\begin{array}{l}\text { In Table } \\
\text { format, but } \\
\text { without } \\
\text { details/purpo } \\
\text { se }\end{array}$ & $\begin{array}{l}\text { Table format } \\
\text { with } \\
\text { details/purpo } \\
\text { se }\end{array}$ \\
\hline 5 & $\begin{array}{l}\text { Carbon } \\
\text { Emission/Ca } \\
\text { rbon } \\
\text { Footprint }\end{array}$ & $\begin{array}{l}\text { Only } \\
\text { theoretically } \\
\text { mentioned }\end{array}$ & $\begin{array}{l}\text { Shown the } \\
\text { procedure by } \\
\text { flow } \\
\text { chart/graphs } \\
\text { etc }\end{array}$ & $\begin{array}{l}\text { Not only } \\
\text { procedure is } \\
\text { mentioned } \\
\text { but also } \\
\text { shown actual } \\
\text { computation } \\
\text { of } \\
\text { instruments/p } \\
\text { rocess }\end{array}$ \\
\hline
\end{tabular}




\begin{tabular}{|c|c|c|c|c|}
\hline $\begin{array}{l}\text { Sr. } \\
\text { No. }\end{array}$ & $\begin{array}{l}\text { Criteria/ } \\
\text { Description }\end{array}$ & $\begin{array}{l}\text { Satisfactory } \\
{[1]}\end{array}$ & $\begin{array}{l}\text { Good } \\
{[2]}\end{array}$ & $\begin{array}{l}\text { Excellent } \\
{[3]}\end{array}$ \\
\hline & & & & $\begin{array}{l}\text { selected and } \\
\text { arrived in } \\
\text { numbers e.g. } \\
\text { Kgs/tons etc }\end{array}$ \\
\hline 6 & $\begin{array}{l}\text { Sustainabilit } \\
\text { y } \\
\text { Computation }\end{array}$ & $\begin{array}{l}\text { Just } \\
\text { mentioned }\end{array}$ & $\begin{array}{l}\text { Mentioned } \\
\text { with units } \\
\text { e.g. } \\
\text { hours/month } \\
\text { s etc }\end{array}$ & $\begin{array}{l}\text { Shown } \\
\text { computations } \\
\text {, flowcharts } \\
\text { also for } \\
\text { sustainability } \\
\text { calculations } \\
\text { specific to } \\
\text { instrument/pr } \\
\text { ocess } \\
\text { selected in } \\
\text { hrs./months } \\
\text { etc }\end{array}$ \\
\hline 7 & $\begin{array}{l}\text { Overall } \\
\text { quality of } \\
\text { video }\end{array}$ & $\begin{array}{l}\text { Generalized } \\
\text { content } \\
\text { No figures, } \\
\text { numbers, } \\
\text { graphs, flow } \\
\text { charts etc } \\
\text { (Textual } \\
\text { Video) }\end{array}$ & $\begin{array}{l}\text { Specific to } \\
\text { subject and } \\
\text { equipment's } \\
\text { selected } \\
\text { without } \\
\text { numbers, } \\
\text { flow charts } \\
\text { etc. }\end{array}$ & $\begin{array}{l}\text { Specific to } \\
\text { subject and } \\
\text { specific to } \\
\text { instrument/pr } \\
\text { ocess/ } \\
\text { software } \\
\text { chosen. All } \\
\text { above } 1 \text { to } 6 \\
\text { criteria } \\
\text { followed. } \\
\text { Graphs/numb } \\
\text { ers/flow } \\
\text { charts are } \\
\text { nicely used }\end{array}$ \\
\hline
\end{tabular}

From above table it is evident that, 21 maximum marks were setup for YouTube video creation. Out of which 15 marks were setup for qualification of FDP completion.

YouTube video was consistently created by all participants as per the rubrics specified and peer review feedback were provided to through moodle. YouTube channel Environment and Sustainability [OE4BW] is created and published in YouTube.[https://www.youtube.com/channel/UCQWwEFd EMeS7Kc3MuWw3Jkg/videos]

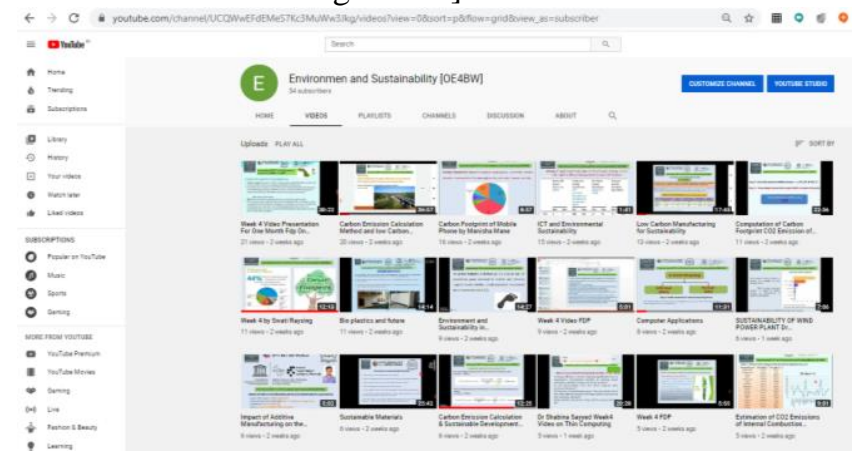

Fig 4: YouTube channel for participants video repository as outcome

Out of 652 participants 268 participants could complete youtube video publication and uploading.

4.0 Discussion and impact analysis of YouTube Assignment Creation for disseminating PO7

YouTube video creation demanded active engagement and only those participants who actively learned concepts and implement, successfully completed this FDP. Detailed rubrics helped to follow roadmap to participants. Other impacts observed are:

1] Helped in learning 17 SDGs of United Nations
2] Analyse subject specific environmental aspects and applications.

3] Case studies underway across globe

4] Assimilated learnings to disseminate in students

5. In-depth understanding of PO7 and its everyday applications

6. Learned usage of Google Meet and Moodle Integration useful to impart post covid-19 online education.

7. New way of thinking towards equipment's and waste management.

8. Participants learned video editor effectively for creating YouTube videos.

9. Understanding of the term sustainability not just restricted to papers and books as text but its role and attainment in daily life as well.

10. Benefit was that we could understand the different policies adopted around the world for conservation of perishable resources with respect to environment and sustainability.

Participant's happiness index for learning was attributed as $\mathrm{A}+[4.79 / 5]$ during the entire video development process.

The same approach was followed for students as well and case study was conducted in College of Engineering Pune for Second Year Engineering Students. 39 students completed YouTube video assignment with 4.7/5 rating specified by other students. $90 \%$ students felt video creation interesting for their subject learning.

\subsection{Conclusion}

Post covid online education system's needs innovative blended pedagogical approaches. Creating YouTube video assignment is one of such activities. Participants were shared case studies by arranging expert lectures, rubrics based guidelines for video creation, peer reviews by participants and updating by participants created learning interests. This increased their learning effectiveness. YouTube based video assignments, thus can be, acknowledged as active learning strategy in online education. MIY model adopted blended learning strategy, as it involved all stakeholders' participation (Student, Teachers, Global Case Studies, and Industrial Knowhow etc).

\section{Acknowledgement}

This project was created in association with Open Education for Better World Project of UNESCO Chair Slovenia in collaboration with University of Nova Gorica, Slovenia, Europe. Authors are also thankful to Asia Hub Coordinators, Dr Jayashree Shinde and Prof. Dr Vasudha Kamat, Anja Polajnar and anonymous reviewers for their inputs and support in making this MIY model creation project successful.

\section{References}

1] Rajendra Pawar, Sushma Kulkarni, Sachin Patil (2020), Project Based Learning: An innovative approach for integrating $21^{\text {st }}$ Century Sills, Journal of Engineering Education Transformation, volume 33, Issue 4, 58-63 doi: 10.16920/jeet/2020/v33i4/139423

2] Trupti S. Indi, Sunita M Dol (2018), Open Education Resource (OER) for advanced C Concepts course using LMS - Moodle for Engineering Education, Journal of 
Engineering Education Transformation, Volume 32, No. 2, $75-81$

doi: 10.16920/jeet/2018/v32i2/139506

3] Deepti Patole, Purnima Ahirao, Yogita Borse (2020), Novel Teaching Learning and Evaluation activities for imbibing the concepts of cyber security as perennial thoughtprocess in the learners' digital life, Journal of Engineering Education Transformation, Volume 33, Special Issue, 376383

\section{Annexures}

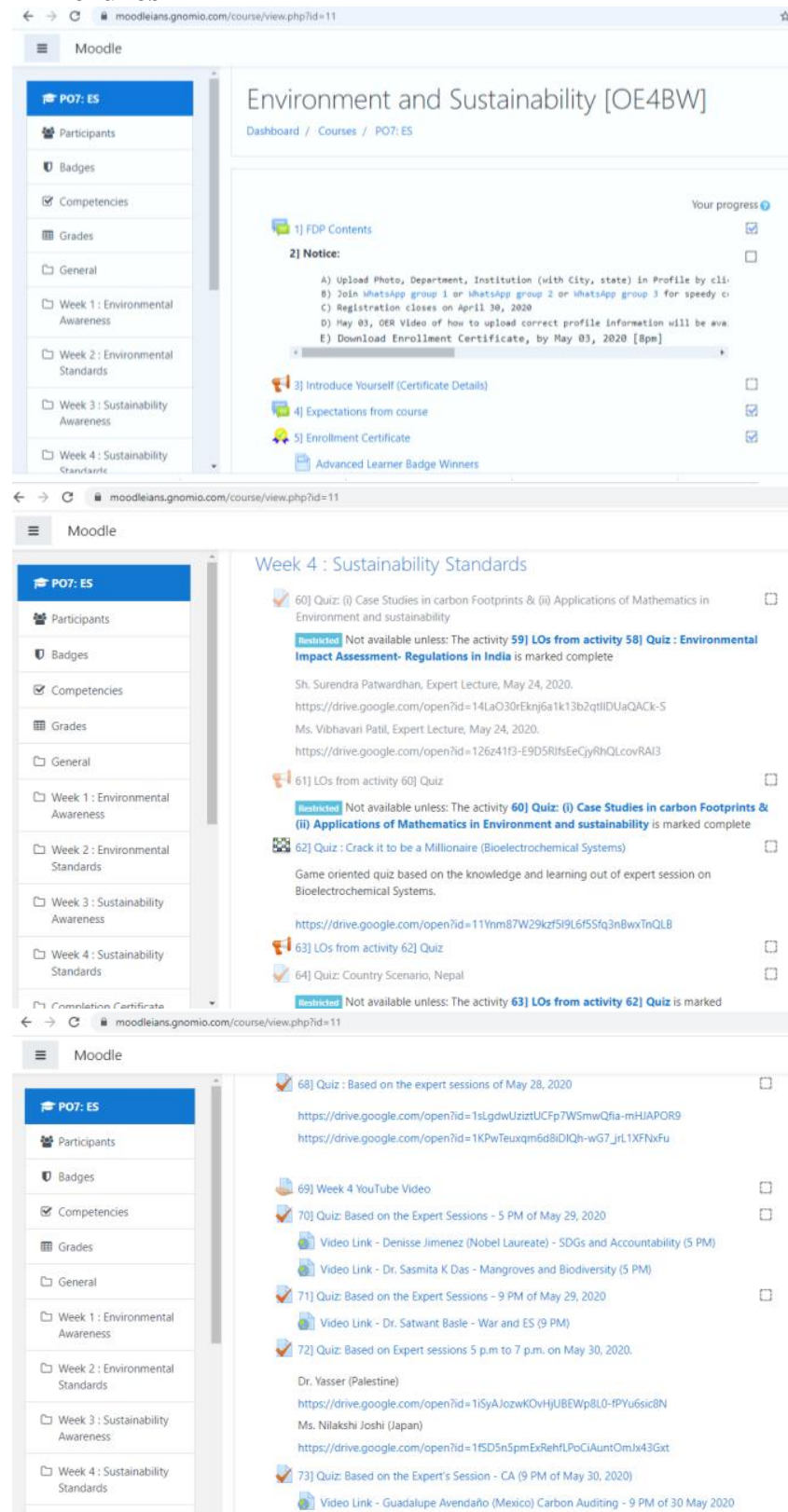

Fig 5: Moodle Course

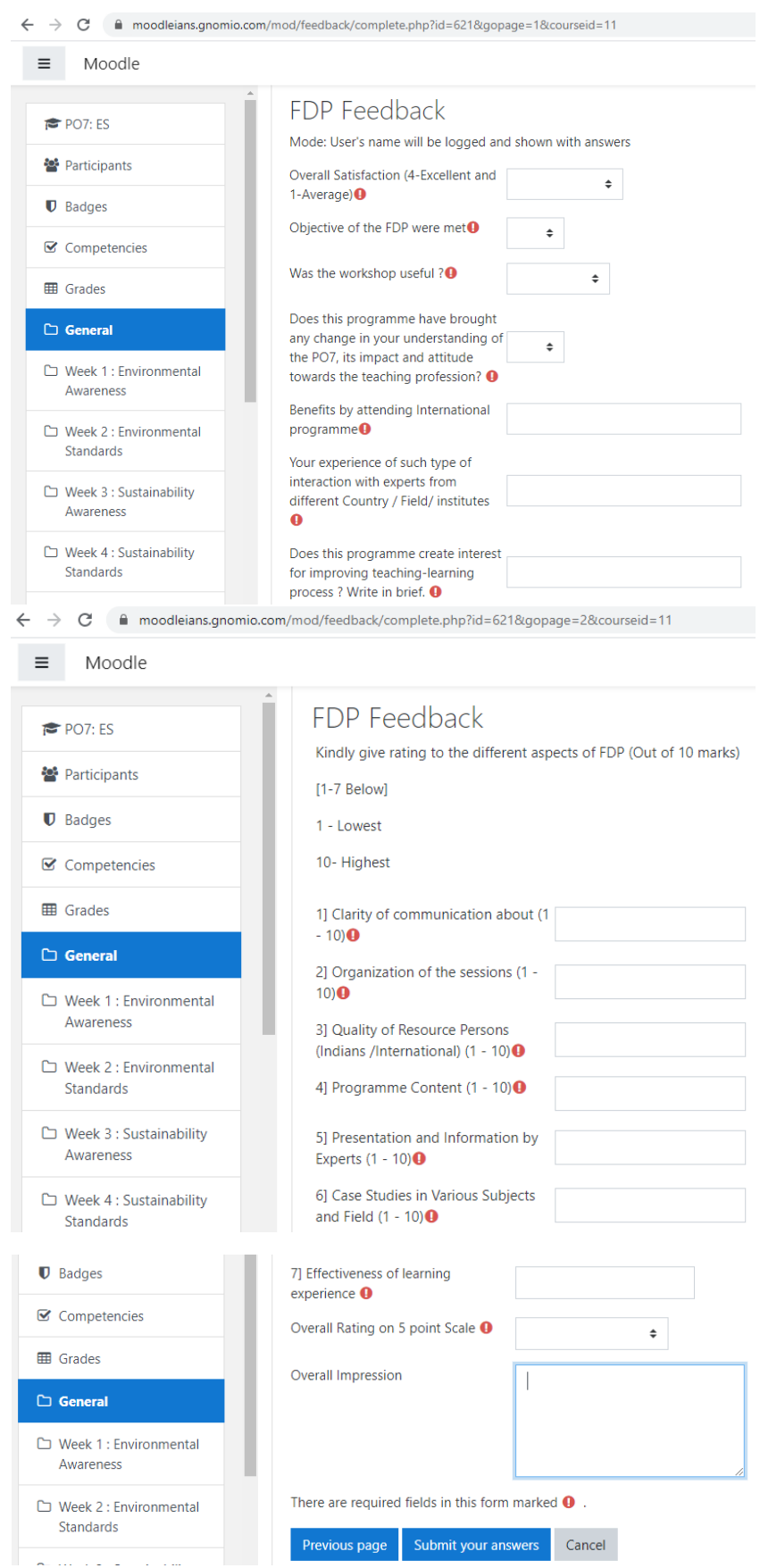

Fig 6: FDP feedback questionnaire for assessment of outcome

Fig 7: Feedback rating from participants

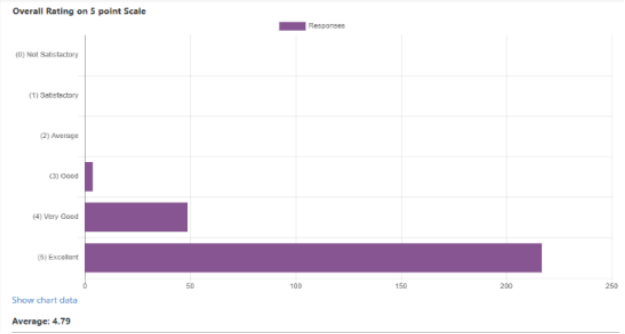

